\title{
Fabrication of $\mathrm{Sm}_{0.5} \mathrm{Sr}_{0.5} \mathrm{CoO}_{3}$ cathode films for intermediate temperature SOFCs by electrostatic spray deposition
}

\author{
Inyu Park, Jongmo Im, Younggeul Jung and Dongwook Shin ${ }^{\dagger}$ \\ Division of Materials Science \& Engineering, Hanyang University, Seoul 133-791, Korea
}

(Received February 17, 2010)

(Revised March 30, 2010)

(Accepted April 2, 2010)

\begin{abstract}
The microstructural change of the $\mathrm{Sm}_{0.5} \mathrm{Sr}_{0.5} \mathrm{CoO}_{3}$ (SSC) electrode for a cathode material of solid oxdie fuel cells (SOFCs) deposited by the electrostatic spray deposition (ESD) technique was characterized. Samarium chloride hexahydrate $\left(\mathrm{SmCl}_{3} \cdot 6 \mathrm{H}_{2} \mathrm{O}\right)$, strontium chloride hexahydrate $\left(\mathrm{SrCl}_{2} \cdot 6 \mathrm{H}_{2} \mathrm{O}\right)$, cobalt nitrate hexahydrate $\left(\mathrm{Co}\left(\mathrm{NO}_{3}\right)_{2} \cdot 6 \mathrm{H}_{2} \mathrm{O}\right)$ as starting materials and methyl alcohol as solvent were used to make precursor solution. The suitable porous SSC films for a cathode of SOFCs were deposited on $\mathrm{Si}$ substrate and it is observed that the microstructure was strongly dependent on processing parameters such as deposition time, substrate temperature, and applied voltage. Scanning Electron Microscope (SEM) and X-ray Diffractometer (XRD) measurement were used to investigate the microstructure and crystallinity of the SSC films. The ESD technique is shown to be an efficient method in which the SOFCs' cathode film can be fabricated with the desired phases and microstructure.
\end{abstract}

Key words SSC, SOFC, Electrostatic Spray Deposition

\section{정전분무증착법에 의한 중온형 고체산화물 연료전지를 위한 $\mathrm{Sm}_{0.5} \mathrm{Sr}_{0.5} \mathrm{CoO}_{3}$ 양극 막의 제조}

박인유, 임종모, 정영글, 신동욱

한양대학교 신소재공학과, 서울, 133-791

(2010년 2월 17일 접수)

(2010년 3월 30일 심사완료)

(2010년 4월 2일 게재확정)

요 약 정전분무증착 기술에 의해 증착된 고체산화물 연료전지(SOFC) 양극재료인 $\mathrm{SSC}$ 양극막의 미세구조적 변화에 대 해 연구하였다. Samarium chloride hexahydrate $\left(\mathrm{SmCl}_{3} \cdot 6 \mathrm{H}_{2} \mathrm{O}\right)$, strontium chloride hexahydrate $\left(\mathrm{SrCl}_{2} \cdot 6 \mathrm{H}_{2} \mathrm{O}\right), \mathrm{cobalt}$ nitrate hexahydrate $\left(\mathrm{Co}\left(\mathrm{NO}_{3}\right)_{2} \cdot 6 \mathrm{H}_{2} \mathrm{O}\right)$ 의 출발 물질과 용매로써 메탄올이 전구체 용액을 제조하는데 사용되었다. $\mathrm{SOFC}$ 의 양극을 위해 적합한 다공성의 SSC 막을 제조하였으며, 그 미세구조가 증착시간, 기판온도, 인가전압 등과 같은 공정변수들에 의존한다는 것을 관찰하였다. 주사전자현미경과 X-ray 회절 패턴이 미세구조와 결정성 분석을 위해 사용되었다. 본 연구를 통해, $\mathrm{ESD}$ 기술이 요구하는 상의 합성과 다공성의 미세구조를 갖는 $\mathrm{SOFC}$ 의 양극막을 제조하는데 효과적인 방법임을 입증하였다.

\section{1. 서}

제3세대 연료전지라 불리는 고체산화물 연료전지(Solid Oxide Fuel Cell, SOFC)는 $600 \sim 1000^{\circ} \mathrm{C}$ 의 고온에서 작 동되므로 기존의 연료전지 중 가장 전력 변환 효율이 높 다. 따라서 $\mathrm{SOFC}$ 가 실용화될 경우 화석연료를 전기에

\footnotetext{
Corresponding author

Tel: +82-2-2220-0503

Fax: +82-2-2220-4011

E-mail: dwshin@hanyang.ac.kr
}

너지로 변환시키는 과정에서 $\mathrm{CO}_{2}$ 의 배출을 기존의 발전 방식에 비해 획기적으로 낮출 수 있다. SOFC 분야 연 구에서 주된 연구 테마 중에 하나는 작동온도를 $600^{\circ} \mathrm{C}$ 이하로 낮추는 것이다. 양극의 성능은 이러한 중온 영역 $\left(500 \sim 800^{\circ} \mathrm{C}\right)$ 에서 연료전지의 작동에 심각한 영향을 미 친다. $\mathrm{La}_{1-\mathrm{x}} \mathrm{Sr}_{\mathrm{x}} \mathrm{MnO}_{3}(\mathrm{LSM})$ 페로브스카이트 구조 재료들 은 높은 열적/화학적 안정성 때문에 $\mathrm{SOFC}$ 를 위한 가장 훌륭한 양극재료들 중의 하나로 여겨진다[1]. LSM이 $800^{\circ} \mathrm{C}$ 이상의 작동온도에서 좋은 성능을 보이는 반면, 작동온도가 낮아짐에 따라 그 성능은 낮은 산소표면교환 
계수(oxygen surface exchange coefficient)와 산소확산 계수(oxygen diffusion coefficient) 때문에 현저하게 감 소한다[2,3]. 이러한 문제를 해결하기 위해, 코발트를 함 유한 페로브스카이트 재료들이 최근의 여러 연구들에서 관심 받고 있다 $[2,4,5]$. 또한, $\mathrm{Sm}_{0.5} \mathrm{Sr}_{0.5} \mathrm{CoO}_{3}(\mathrm{SSC})[6,7]$, $(\mathrm{La}, \mathrm{Sr}) \mathrm{CoO}_{3}(\mathrm{LSC})[8],(\mathrm{La}, \mathrm{Sr})(\mathrm{Co}, \mathrm{Fe}) \mathrm{O}_{3}(\mathrm{LSCF})[9]$ 와 같은 코발트를 함유한 물질들은 이온-전자 혼합 전도체 (mixed ionic-electronic conductor, MIEC)이고 이들은 높 은 산소 공공 농도 때문에 LSM 양극 보다 더 높은 이온 전도를 보이며, 이는 전기화학적으로 활성화된 영역인 3 상계면이 전해질과 전극 사이의 계면에서 이온-전자 혼합 전도체 전체 영역으로 확장되었음을 의미한다[10]. 특히, 스트론튬이 첨가된 사마륨 코발타이트 $\left(\mathrm{Sm}_{1-x} \mathrm{Sr}_{\mathrm{x}} \mathrm{CoO}_{3}\right.$ : $\mathrm{SSC}$ )는 $\mathrm{x}=0.5$ 일 경우에 $10^{3} \mathrm{~S} \mathrm{~cm}^{-1}$ 이상의 높은 전도 도를 보이고 낮은 과전압으로 인해 $\mathrm{SOFC}$ 의 양극물질 연구에서 크게 주목 받고 있다[11, 12].

$\mathrm{SOFC}$ 를 위한 양극의 미세구조는 산소 가스가 양극 내에서 전자와 결합하고 산소이온이 양극을 통해 전해질 로 이동해야 하기 때문에 적당한 기공률을 가져야 한다. 정전분무증착(Electrostatic Spray Deposition, ESD)는 높은 기공률, 높은 증착 효율 $(80 \%$ 이상 $)$, 간단한 장치, 빠른 증착율, 막의 미세구조를 제어하는 것의 편리성, 원 료 물질 선택의 다양성과 같은 $\mathrm{SOFC}$ 의 양극막을 제조 하기 위한 많은 장점들을 가지고 있다[13]. 하지만 ESD 기술은 $\mathrm{SOFC}$ 의 다공성 구조의 양극막을 증착하는 데 아직 활발히 연구되고 있지 않다. 따라서, 본 연구에서, $\mathrm{SOFC}$ 의 양극재료에서 요구하는 다공성의 구조를 갖는 $\mathrm{SSC}$ 양극막을 제조하는 데 적합한 기술임을 증명하기 위하여 본 연구를 진행하였다.

\section{2. 실험방법}

Samarium chloride hexahydrate $\left(\mathrm{SmCl}_{3} \cdot 6 \mathrm{H}_{2} \mathrm{O},>99.0 \%\right.$, Sigma-Aldrich Co.), strontium chloride hexahydrate $\left(\mathrm{SrCl}_{2} \cdot 6 \mathrm{H}_{2} \mathrm{O},>99.0 \%\right.$, Junsei $\mathrm{Co}$.), 그리고 cobalt nitrate hexahydrate $\left(\mathrm{Co}\left(\mathrm{NO}_{3}\right)_{2} \cdot 6 \mathrm{H}_{2} \mathrm{O},>98.0 \%\right.$, SigmaAldrich Co.)가 출발 물질로써 사용되었다. 우선, 0.5 몰의 $\mathrm{SmCl}_{3} \cdot 6 \mathrm{H}_{2} \mathrm{O}, 0.5$ 몰의 $\mathrm{SrCl}_{2} \cdot 6 \mathrm{H}_{2} \mathrm{O}, 1$ 몰의 $\mathrm{Co}\left(\mathrm{NO}_{3}\right)_{2}$. $6 \mathrm{H}_{2} \mathrm{O}$ 를 $40 \mathrm{~m} /$ 의 메탄올에 녹여 전체 몰농도를 0.1 몰로 하였다. 그 다음에, 준비된 전구체 용액의 용해도를 높이 기 위해 상온에서 약 30 분 간 교반하였다.

본 연구에서 이용된 ESD system은 Fig. 1에 도식적으 로 나타내었다. 전구체 용액은 주사기로부터 노즐(내경 $0.03 \mathrm{~mm}$, Nano N.C. Co.)로 주사기 펌프(KD Scientific Co.)를 이용해 공급된다. 노즐의 끝에서 용액은 노즐과 기판 사이에 작용하는 정전기적 힘에 의해 미립화되고,

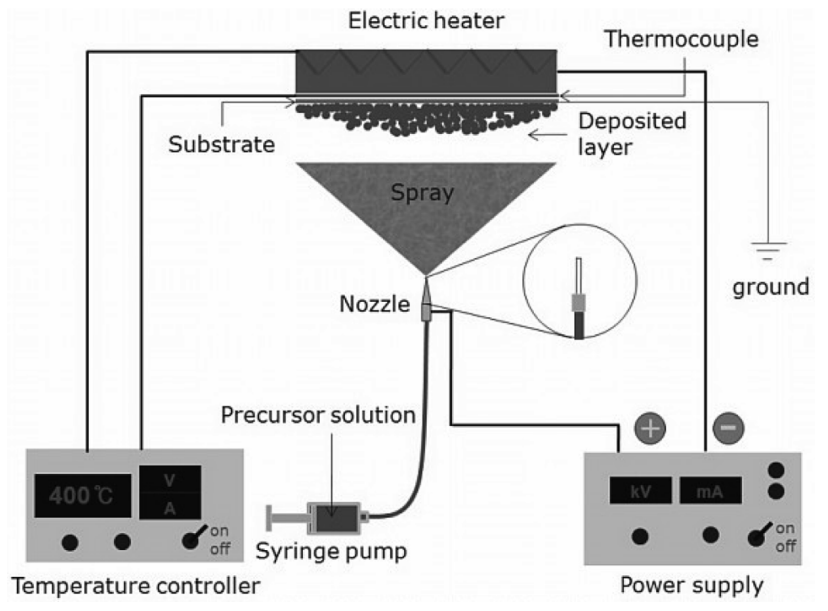

Fig. 1. Schematic design of electrostatic spray deposition (ESD) system.

미세한 액적을 형성한다. 그 액적은 온도 컨트롤러에 의 해 가열된 기판 위에 증착되고 대기 중에서 증착이 이루 어진다. 열전대와 전기 가열기가 차례로 기판의 뒤쪽으 로부터 놓인다. 본 연구를 통해, 증착시간, 기판온도, 인 가전압 의한 막의 미세구조에 미치는 영향을 연구하였다.

$\mathrm{ESD}$ 에 의해 형성된 막의 미세구조는 주사전자현미경 (JEOL, Co., JCM-5700)을 이용하여 관찰하였으며, 합성 된 상의 결정성은 X-ray 회절분석기(Rigaku Co. Ultima IV)를 이용하여 분석하였다.

\section{3. 실험결과 및 고찰}

\section{1. 증착시간의 영향}

증착시간은 3 분에서 10 분까지 변화시켰고, 각기 다른 증착시간을 갖는 막의 미세구조가 Fig. 2에 보이는 것처 럼 관찰되었다. 막은 상향식의 정전분무증착 방법에 의 해 $\mathrm{Si}$ 기판 위에 기판온도 $350^{\circ} \mathrm{C}$ 에서 증착되었다. 증착 된 막의 미세구조는 증착시간 3 분 일 경우에 상대적으 로 치밀하고, 증착시간이 10 분 까지 증가함에 따라 점점 다공성의 막으로 바뀌었으며 막의 두께가 증착시간 3 분 일 때, 약 $1.7 \mu \mathrm{m}, 5$ 분 일 때, $3.3 \mu \mathrm{m}, 10$ 분 일 때, 약 $6.3 \mu \mathrm{m}$ 로 점차적으로 두꺼워졌으며, 평균적으로 약 $0.6 \mu \mathrm{m} /$ 분의 증착율을 보였다. 이러한 현상은 액적의 증발률과 퍼짐률의 관계로 설명될 수 있다[14]. 노즐로 부터 인가 전압에 의해 미립화 되고 분무된 거의 모든 액적들은 기 판에 도달한 후에도 여전히 용매를 포함하고 있다. 액적 이 처음으로 $\mathrm{Si}$ 기판에 도달하면, 분무된 액적은 금속 기판 위에 빠르게 퍼질 수 있는 양의 용매를 포함하고 있기 때문에 금속 기판을 적시게 되고, 따라서 조밀한 

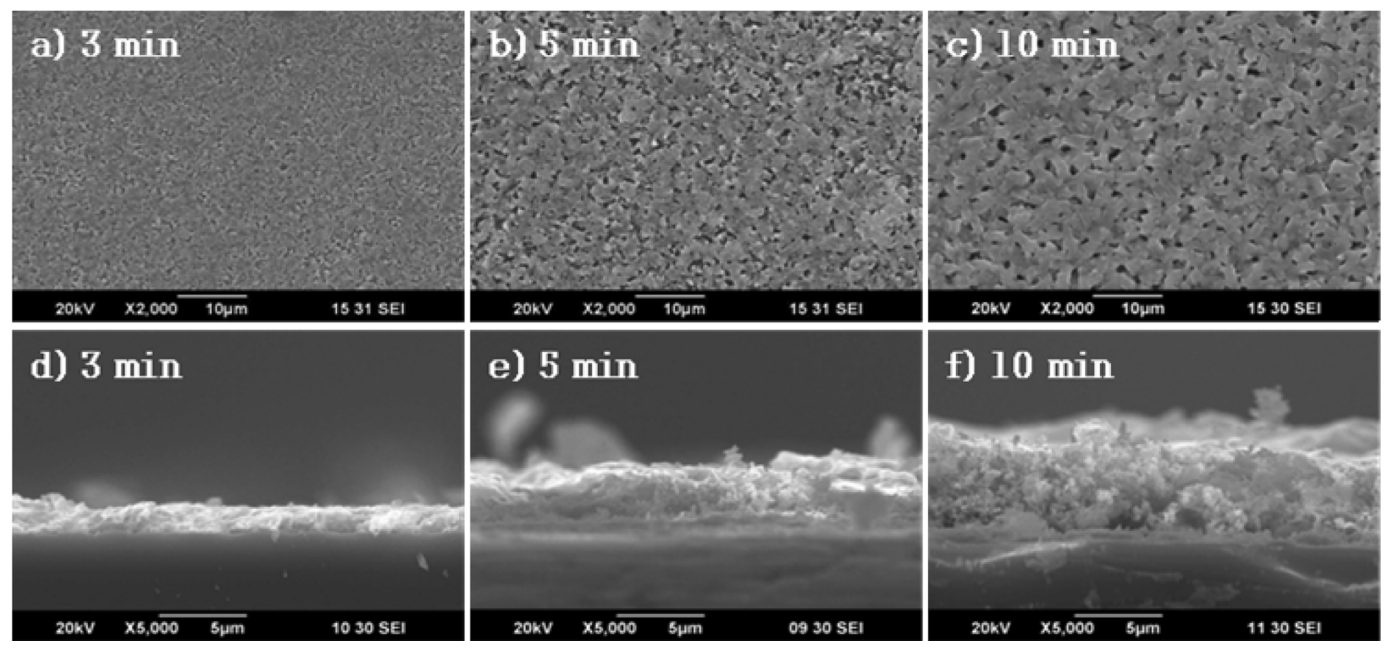

Fig. 2. SEM micrographs of SSC films deposited on silicon wafers with conditions of the substrate temperature of $350^{\circ} \mathrm{C}$, the flow rate of $4.5 \mathrm{ml} / \mathrm{h}$, the distance between the nozzle and the substrate of $4 \mathrm{~cm}$, the applied voltage of $13 \mathrm{kV}$, and the various deposition time of 3, 5, and $10 \mathrm{~min}$; (a), (b), (c) are surface images and (d), (e), (f) are cross-sectional images.

구조를 형성하게 된다. 하지만, 증착시간이 증가함에 따 라, 차례로 기판에 도달하는 액적들은 표면이 매끄러운 금속 기판이 아닌 이미 $\mathrm{Si}$ 기판에 도달하여 표면을 덮고 있는 $\mathrm{SSC}$ 산화물 위에 증착된다. 이 경우에, 액적은 $\mathrm{Si}$ 기판 표면에서의 표면장력보다 SSC 산화물 위에서의 표 면장력이 더 작기 때문에 적심각이 커지게 되고, 따라서 액적은 증착시간이 증가하면서 다공성의 구조로 변화하 게 된다[14].

\section{2. 기판온도의 영향}

Fig. 3 은 각기 다른 기판 온도에서 증착된 $\mathrm{SSC}$ 막의 다양한 미세구조를 보여준다. Fig. 3에 보이는 것처럼 기판온도가 $300^{\circ} \mathrm{C}$ 에서 $500^{\circ} \mathrm{C}$ 로 증가하면서 심한 $\mathrm{crack}$ 이 발생하고 있다. 기판온도 $300^{\circ} \mathrm{C}$ 의 경우 낮은 기판 온도로 인해 분무된 액적들이 기판에 도달하기까지 입자 를 형성할 만큼 용매의 충분한 증발이 이루어지지 않고 기판을 완전히 적셔 전체적으로 조밀한 구조를 나타내었 다. 하지만 기판 온도가 $400^{\circ} \mathrm{C}$ 로 증가하면서 점차 기판
에 가해지는 열적 스트레스가 커지면서 crack이 발생하 기 시작한다. 기판온도가 $500^{\circ} \mathrm{C}$ 로 더욱 증가하게 되면 crack의 정도가 더 심해지고 노즐에서 분무된 액적이 기 판에 도달하는 과정에서도 액적이 가진 용매가 충분히 증발하기 때문에 기판에 도달한 액적들이 기판을 충분히 적시지 못하고, 따라서 증착 표면이 거칠어 지고 또한 심한 열적 스트레스로 인해 깊은 crack을 동반하게 되는 것으로 사료된다.

\section{3. 인가전압에 의한 영향}

Fig. 4는 용액을 작은 액적으로 미립화하여 분무하기 위한 서로 다른 인가전압 하에서 증착된 $\mathrm{SSC}$ 양극막의 미세구조 변화를 나타낸다. 그림에서 보여지는 바와 같 이, $10 \mathrm{kV}$ 의 인가전압에서는 상대적으로 조밀한 구조의 막을 형성하였고 전압이 증가함에 따라서 공극률이 점차 적으로 증가함을 보였다. 이는 용액을 미립화하여 분무 하기 위한 인가전압과 분무된 액적 방울의 크기와의 관 계로써 설명되어 질 수 있다[15].
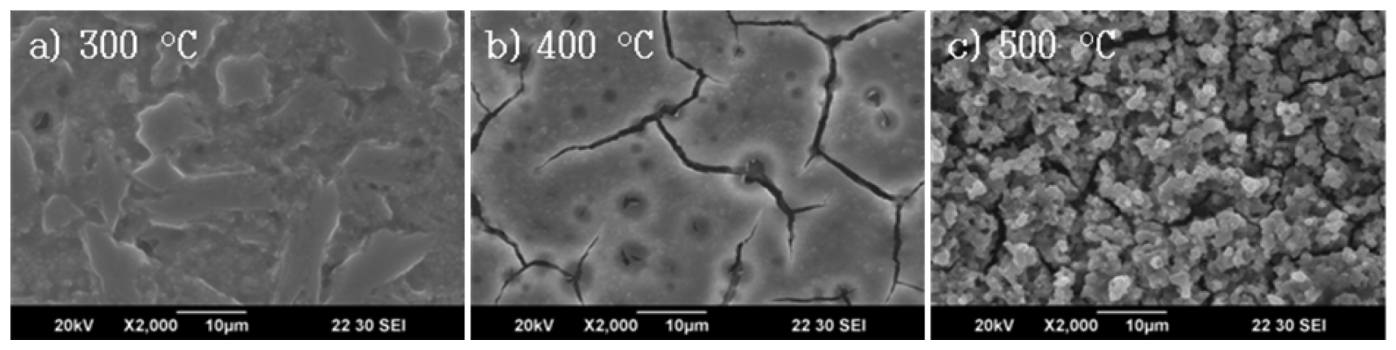

Fig. 3. SEM micrographs of SSC films deposited on silicon wafers with conditions of the applied voltage of $13 \mathrm{kV}$, the flow rate of $4.5 \mathrm{ml} / \mathrm{h}$, the distance between the nozzle and the substrate of $4 \mathrm{~cm}$, the deposition time of $5 \mathrm{~min}$, the substrate temperature of (a) $300^{\circ} \mathrm{C}$, (b) $400^{\circ} \mathrm{C}$, (c) $500^{\circ} \mathrm{C}$. 

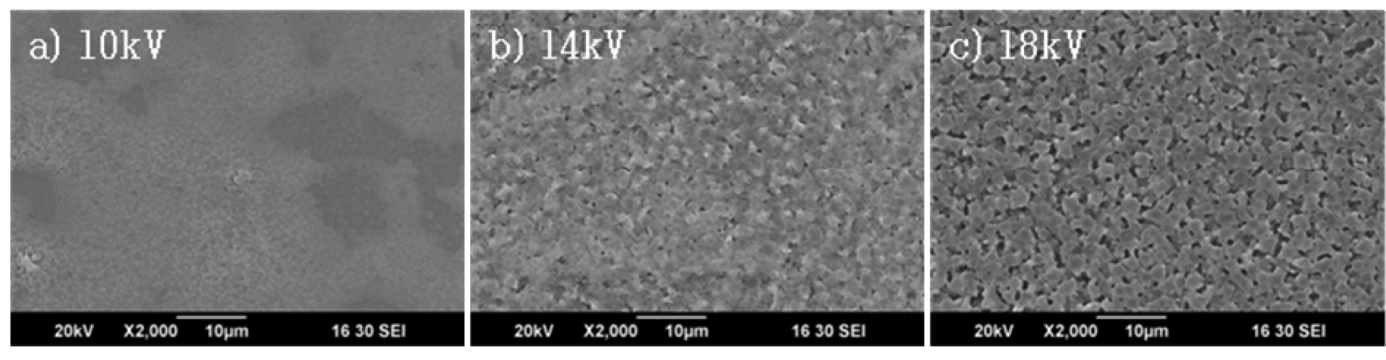

Fig. 4. SEM micrographs of SSC films deposited on silicon wafers with conditions of the substrate temperature of $350^{\circ} \mathrm{C}$, the flow rate of $4.5 \mathrm{ml} / \mathrm{h}$, the distance between the nozzle and the substrate of $4 \mathrm{~cm}$, the deposition time of $5 \mathrm{~min}$, the applied voltage of (a) $10 \mathrm{kV}$, (b) $14 \mathrm{kV}$, (c) $18 \mathrm{kV}$.

Ganan-Calvo et al.[15]은 용액을 미립화하기 위한 노 즐에 가해지는 인가전압이 증가할수록 분사되는 액적의 크기는 감소한다고 보고하였다. 다시 말해서, 작은 힘(작 은 인가전압)에 의해서 미립화된 큰 액적은 기판에 도달 한 후에도 여전히 기판에 퍼지기 위한 충분한 용매를 포 함하고 있고 쉽게 기판을 적실 수 있기 때문에 조밀한 구조를 형성한다. 반면에 큰 인가전압에 의해 미립화된 액적은 작은 인가전압에 의해 분무된 액적에 비해 상대 적으로 작은 크기이며 이는 기판으로 이동하는 동안에 용매의 충분한 증발이 일어나기 때문에 기판에 도달 후 에 완전히 퍼지지 못하고 다공성 구조를 형성하게 된다.

또한, 이러한 인가전압에 의한 미세구조 변화는 분무 된 액적의 크기와 그 액적이 가질 수 있는 최대전하량의 관계에 의해서도 설명 될 수 있다[16]. 전하를 띠는 액 적은 이차분열을 하게 되는데, 액적 크기가 작을 수록 용매의 증발이 빨리 일어나 하전된 액적이 가질 수 있는 최대 전하량, Rayleigh limit에 더 빠르게 도달하게 되어 불안정한 상태가 된다. 이렇게 되면 액적들은 안정한 상 태를 유지하기 위해 더 작은 액적들로 다시 분열을 하게 되는데 이를 이차분열이라고 한다[16]. 이차분열이 이루 어진 더 작은 액적들은 그 만큼 더 빠른 용매의 증발을 야기하게 되므로 기판에 도달한 후에 더 많은 용매를 포 함하고 있는 낮은 인가전압에서의 액적들 보다 기판에 잘 퍼지지 못하고 다공성의 막을 형성하게 되는 것이다.

\subsection{SSC 양극막의 결정성 분석}

$\mathrm{ESD}$ 법에 의해 증착된 $\mathrm{SSC}$ 양극막의 소결 온도에 따 른 X-ray 회절 패턴을 Fig. 5에 나타내었다. 결정성 분 석을 위해 $18 \mathrm{kV}$ 의 인가전압, $350^{\circ} \mathrm{C}$ 의 기판온도, 증착 시간 5 분의 조건 하에서 시편을 준비하였다. 각각의 Xray 회절 패턴을 통해서 원하는 페로브스카이트 구조의 $\mathrm{SSC}$ 양극막이 합성된 것을 확인할 수 있었다. 또한, $600 \sim 800^{\circ} \mathrm{C}$ 에서 이차상 없는 단일 $\mathrm{SSC}$ 를 합성할 수 있 었고[6], $800^{\circ} \mathrm{C}$ 에서 가장 좋은 결정성을 갖는 $\mathrm{SSC}$ 양극 막을 확인하였다.

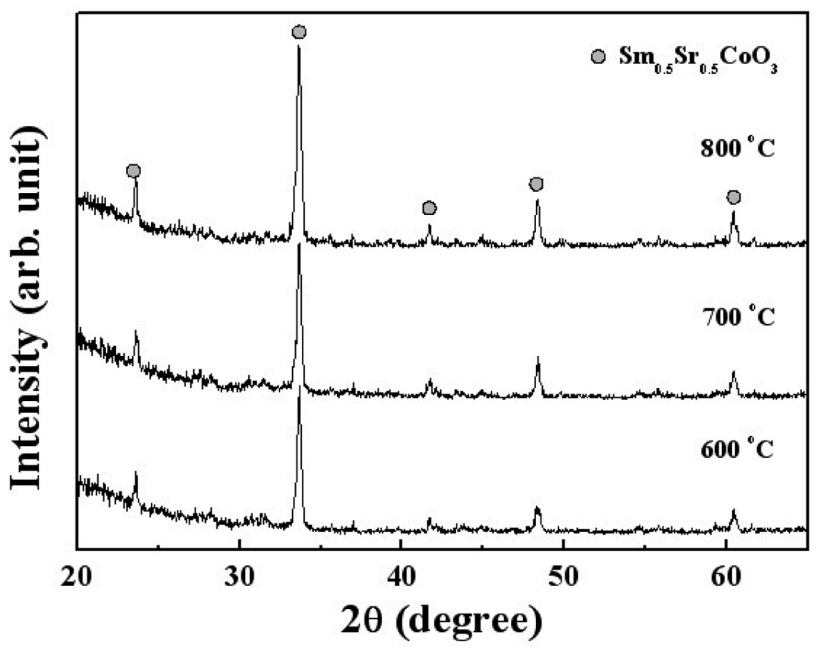

Fig. 5. X-ray diffraction patterns of SSC films sintered at $600^{\circ} \mathrm{C}, 700^{\circ} \mathrm{C}$, and $800^{\circ} \mathrm{C}$.

\section{4. 결 론}

본 연구를 통해서 정전분무증착법(Electrostatic Spray Deposition, ESD)의 다양한 공정변수가 고체산화물 연료 전지의 양극 물질인 $\mathrm{SSC}$ 의 미세구조에 미치는 영향에 대해서 고찰하였다. $\mathrm{ESD}$ 법의 변수들을 조절하여 각 변 수 변화에 따른 $\mathrm{SSC}$ 양극막의 미세구조 관찰 결과, 증 착시간이 늘어남에 따라 조밀한 구조에서 다공성 구조로 변화하였고, 기판 온도가 증가함에 따라 열적 스트레스 로 인한 깊은 crack이 발생하였으며, 인가전압이 높아짐 에 따라 조밀한 구조에서 다공성 구조로 변화됨을 관찰 하였다. 이를 통해, $\mathrm{ESD}$ 가 $\mathrm{SOFC}$ 의 다공성 구조를 요하 는 양극막 제조에 탁월한 효과가 있음을 확인하였다.

\section{감사의 글}

이 논문은 2009년도 정부(교육과학기술부)의 재원으로 한국과학재단의 지원을 받아 수행된 연구임(No. 2009- 


\section{참 고 문 헌}

[1 1 S.C. Singhal, "Advances in solid oxide fuel cell", Solid State Ionics 135 (2000) 305.

[2 ] K.L. Choy, S. Charojrochkul and B.C.H. Steele, "Fabrication of cathode for solid oxide fuel cells using flame assisted vapour deposition technique", Solid State Ionics 96 (1997) 49.

[ 3 ] R. Doshi, VL. Richards, J.D. Carter, X. Wang and M. Krumpelt, "Development of solid-oxide fuel cells that operate at $500^{\circ} \mathrm{C} "$, J. Electrochem. Soc. 146 (1999) 1273.

[4] E. Maguire, B. Gharbage, F.M.B. Marques and J.A. Labrincha, "Cathode materials for intermediate temperature SOFCs", Solid State Ionics 127 (2000) 329.

[ 5 ] V. Dusastre and J.A. Kilner, "Optimisation of composite cathodes for intermediate temperature SOFC applications", Solid State Ionics 126 (2000) 163.

[6] C.R. Xia, W. Rauch, F.L. Chen and M.L. Liu, " $\mathrm{Sm}_{0.5} \mathrm{Sr}_{0.5} \mathrm{CoO}_{3}$ cathodes for low-temperature SOFCs", Solid State Ionics 149 (2002) 11.

[ 7 ] Z. Tang, Y. Xie, H. Hawthorne and D. Ghosh, "Sol-gel processing of $\mathrm{Sr}_{0.5} \mathrm{Sm}_{0.5} \mathrm{CoO}_{3}$ film", J. Power Sources 157 (2006) 385.

[ 8 ] S. Zha, W. Rauch and M. Liu, "Ni-Ce ${ }_{0.9} \mathrm{Gd}_{0.1} \mathrm{O}_{1.95}$ anode for GDC electrolyte-based low-temperature SOFCs", Solid State Ionics. 166 (2004) 241.

[9] W. Wang and M. Mogensen, "High-performance lanthanum-ferrite-based cathode for SOFC", Solid State Ionics 176 (2005) 457.

[10] X. Zhang, M. Robertson and S. Yick, " $\mathrm{Sm}_{0.5} \mathrm{Sr}_{0.5} \mathrm{CoO}_{3}+$ $\mathrm{Sm}_{0.2} \mathrm{Ce}_{0.8} \mathrm{O}_{1.9}$ composite cathode for cermet supported thin $\mathrm{Sm}_{0.2} \mathrm{Ce}_{0.8} \mathrm{O}_{1.9}$ electrolyte $\mathrm{SOFC}$ operating below $600^{\circ}$ C", J. Power Sources 160 (2006) 1211.

[11] T. Ishihara and M. Honda, "Intermediate temperature solid oxide fuel cells using a new $\mathrm{LaGaO}_{3}$ based oxide ion conductor", J. Electrochem. Soc. 145 (1998) 3177.

[12] Y. Liu, S. Zha and M. Liu, "Novel nanostructured electrodes for solid oxide fuel cells fabricated by combustion chemical vapor deposition (CVD)", Adv. Mater. 16 (2004) 256.

[13] J.M. Im, I.Y. Park, S.E. Jang and D.W. Shin, "Fabrication of porous lanthanum strontium manganite films by electrostatic spray deposition", Met. Mater. Int. 15 (2009) 1.

[14] C. Chen, E.M. Kelder and J. Schoonman, "Morphology control of thin $\mathrm{LiCoO}_{2}$ films fabricated using the electrostatic spray deposition (ESD) technique", J. Mater. Chem. 6 (1996) 765.

[15] A.M. Ganan-Calvo, J. Davila and A. Barrero, "Current and droplet size in the electrospraying of liquids. Scaling laws", J. Aerosol Sci. 28 (1997) 249.

[16] D. Fotiadis, Y. Liang, S. Filipek and K. Palczewski, "Rayleigh jets from levitated microdroplets", Nature 421 (2003) 128. 